\title{
Parametric Model \\ of Real Estate Valuation for Land Located in Different Land-Use Zones**
}

\begin{abstract}
Various spatial planning conditions result in the establishment of lines delimiting specific land-use classes. These lines often cross cadastral boundaries. In this way, individual land properties may be located in different land-use zones. Since the land-use class is one of the attributes that significantly influences the market value of real estate, it seems reasonable to verify whether the non-homogeneous land use of a property should be included in its valuation procedure in a special way.

One of the options of special procedure in this case is dividing the transaction prices obtained for real properties similar to the one being valued (covered by different land-use zones) into components of those prices that correspond to fragments of the property that have different land uses. This procedure is made possible by some statistical models that can be used in a comparative approach. This paper aims to present the possibility of using a parametric model for the valuation of land properties located in different land-use zones and to verify whether it is reasonable to consider non-homogeneity in land-use classes when determining the value of land.
\end{abstract}

Keywords: parametric model, areas of different land uses, land use of the property, real estate valuation

\footnotetext{
* AGH University of Science and Technology, Faculty of Mining Surveying and Environmental Engineering, Department of Geomatics, Krakow, Poland

** This study has received the financial support from the statutory research no. 11.11.150.006.
} 


\section{Introduction}

Pursuant to the Real Estate Management Act [1], the appropriate approach, method, and technique for real estate valuation is selected by a real estate appraiser. For a proper performance of this task, the appraiser must take into account the purpose of valuation, the type and location of the property being valued, its land use in the local zoning plan, its condition, and available data on the prices, income, and characteristics of properties similar to the one being valued. As is the case with most property valuations performed, prices should be adjusted for differences in attributes between comparable real estate and the property being valued. These attributes usually constitute a given set in which two subsets can be identified [25]. The first one includes characteristics defining the similarity of the objects contained in the database of the real properties similar to the one being valued. In each valuation procedure, these attributes must be characterized at the stage of objective description of the local real estate market. The Real Estate Management Act [1] identifies several of these attributes as mandatory. These include legal status of the property being valued, its land use in planning documents, and its actual manner of use. The second subset includes the attributes, based on which the level of prices of the real estate collected in the comparable database shall be adjusted.

The value of real estate largely depends on the possibility of its use for specific purposes [15]. These intended uses are set out in various planning documents, taking the planning and zoning regulations into account [2]. The land-use class of a property defined in these documents is one of those characteristics that should be identical for all properties contained in the database of properties similar to the one being valued. The construction of such a comparable database seems to be much easier when the properties have homogeneous land use. Although the lines delimiting the areas of different land uses should be consistent with cadastral boundaries [11], such an implementation is not always possible in the actual planning space [6]. As a result, a property can be located in different land-use zones. If such a property is subjected to a valuation procedure, finding real estate that would be similar might pose some problems. Not only should comparable properties be located in the same areas, but the proportions of the surface areas of individual land-use zones in each property should also be similar.

Since the misdetermination of the land use of a property may result in a misestimation of its value [7], it may be the same case if real estate values are determined based on similar properties whose fragments of land uses are different than those of the property being valued - the different composition of the areas of various land uses or different proportions of the surface areas of individual land uses. The use of such methods as a pairwise comparison or mean price adjustment may not be sufficient in determining the value of such properties. The unit price determined by these methods may prove to not be representative of a given real estate market due to the highly diversified configuration of the various land-use zones. For such properties, 
it would seem reasonable to separate the unit values of specific land-use zones from their total transaction price. The selection of the right model from the method of statistical analysis of the market allows us to solve this problem.

This paper aims at verifying whether it is important to consider non-homogeneity in land-use classes when determining the value of land and presenting the possibility of using a parametric model for the valuation of land located in different land-use zones, which has long been used to adjust the observation results in surveying $[13,22,24]$.

In real estate valuation, this model has already been used to estimate the market value of built-up lands $[3,4,9,10,14,17-21]$ and of agricultural and forest lands $[17,21]$ as well as the costs of construction and total wear of building structures [5, 8].

The model is based on an analysis of the total transaction price for the whole property, and the unit values of land components are the estimated parameters here. It can be used when the number of transactions constituting similar properties is higher than the total number of elements that are components of the analyzed properties as well as the number of attributes that form the basis for adjusting the prices for the real estate collected in the comparable database. The parameters of this model are estimated using the method of least squares. Based on these, the unit values that are parts of the analyzed properties of the different land-use zones are determined. The results form the basis for determining the market value of the real estate similar to the property under consideration.

\section{Methodology of Property Valuation Using the Parametric Model}

In order to divide the transaction price of a land property that is covered by different land-use zones into price components corresponding to the fragments with a specified land use, the equations in the form (1) should be built as follows:

$$
C_{T j}=S_{1} \cdot c_{1}+S_{2} \cdot c_{2}+\ldots+S_{i} c_{i} \Leftrightarrow p_{j}
$$

where:

$C_{T j}$ - transaction price of the whole $j$-th property,

$S_{i}$ - surface area of the specific land-use class, as the $i$-th element of the $j$-th property,

$c_{i}$ - unit price of the $i$-th component of the property,

$p_{j}$ - weights of mutual similarity among the properties used for the construction of the model, determined by Formula (2):

$$
p_{j}=\frac{1}{0.25+\sum_{s=1}^{n}\left(a_{j s}-\hat{a}_{s}\right)^{2}}
$$


Weights are calculated on the assumption that, in the analyzed database of real estate similar to the property being valued, the most-representative real properties are those whose attributes are close to their average values $\left(\hat{a}_{s}\right)$.

If all of the attributes describing the real estate on which the model is based and the attributes of the real estate being valued are identical, the weighing matrix becomes a unit matrix, which greatly simplifies the calculations.

If necessary, the transaction prices must, of course, be updated as of the valuation date.

In this equation, the unknowns (parameters) are the unit prices of the $i$-th element of the property. For several transaction prices of the real properties similar to the valued one, the system of equations (1) written in the matrix form takes the following form (3):

$$
\left\{C_{T}\right\}=\{S\} \cdot\{c\}+\left\{\delta_{T}\right\} \Leftrightarrow\{p\}
$$

where:

$\left\{C_{T}\right\}$ - vector of transaction prices for the whole properties,

$\{S\}$ - vertical rectangular matrix, formed from the surface areas of components of individual properties,

$\{c\}$ - vector of unit prices of individual components of the analyzed properties,

$\left\{\delta_{T}\right\}$ - vector of random deviations of the model from real estate transaction prices,

$\{p\}$ - weighing matrix of mutual similarity among the analyzed properties.

The system of equations (3) satisfies the Gauss-Markov conditions (4). It has a solution in the set of real numbers if the number of transactions $(j)$ is greater than the sum of the number of the analyzed components of the property (i) and the number of attributes used to describe these properties (s):

$$
\begin{gathered}
E\left\{C_{T}\right\}=\{S\} \cdot\{c\} \Rightarrow E\left[\delta_{T}\right]=\{0\} \\
E\left[\left\{\delta_{T}\right\}^{T} \cdot\left\{\delta_{T}\right\}\right]=V\left[C_{T}\right]=\sigma^{2} \cdot\{I\}
\end{gathered}
$$

The estimator of the vector of unit prices of the property components $\{\hat{c}\}$ are derived directly from normal equations according to Formula (5):

$$
\{\hat{c}\}=\left(\{S\}^{T} \cdot\{p\} \cdot\{S\}\right)^{(-1)} \cdot\{S\}^{T} \cdot\{p\} \cdot\left\{C_{T}\right\}
$$

The estimator of random deviations from transaction prices $\left\{\hat{\delta}_{T}\right\}$ is derived from Formula (6) by substituting Formula (5) into Formula (3):

$$
\left\{\hat{\delta}_{T}\right\}=\left\{C_{T}\right\}-\{S\} \cdot\left(\{S\}^{T} \cdot\{p\} \cdot\{S\}\right)^{(-1)} \cdot\{S\}^{T} \cdot\{p\} \cdot\left\{C_{T}\right\}
$$


The estimator of random deviations from the transaction prices $\left(\hat{\sigma}_{0}^{2}\right)$ is derived from Formula (6) by substituting Formula (5) into Formula (3):

$$
\hat{\sigma}_{0}^{2}=\frac{\left\{C_{T}\right\}^{T} \cdot\{p\} \cdot\left\{C_{T}\right\}-\left\{\hat{c}^{(T)} \cdot\{S\}^{T} \cdot\{p\} \cdot\left\{C_{T}\right\}\right.}{j-i-s}
$$

The formula for the covariance matrix of the vector model unit prices $\{\hat{c}\}$ is derived from the analysis of variance and ultimately takes the following value (8):

$$
\operatorname{cov}\{\hat{c}\}=\hat{\sigma}_{0}^{2}\left(\{S\}^{T} \cdot\{p\} \cdot\{S\}\right)^{-1}
$$

The covariance matrix of the vector of random deviations from the transaction prices is derived from an analysis of the variance of the dependence (3). Consequently, the covariance matrix of the vector of random deviations from the transaction prices $\left\{\hat{\delta}_{T}\right\}$ is expressed by Formula (9):

$$
\operatorname{cov}\left\{\hat{\delta}_{T}\right\}=\sigma_{0}^{2}\left(\{p\}^{-1}-\{S\}\left(\{S\}^{T} \cdot\{p\} \cdot\{S\}\right)^{-1}\{S\}^{T}\right)
$$

Elements of the covariance matrix of the vector of unit prices of the property components $\{\hat{c}\}$ are used to assess the inaccuracy of model unit prices and to analyze the variance of the estimated market values of the real estate being valued. Elements of the covariance matrix of the vector of random deviations from the transaction prices $\left\{\hat{\delta}_{T}\right\}$ are used to analyze the variance of adjusted unit prices of the real estate components that make up the model.

Calculated for each transaction, random deviations from the transaction prices $\left\{\hat{\delta}_{T}\right\}$ are decomposed proportionally to the prices of individual components of the property in order to calculate the model values of its subsequent components $\left(\bar{c}_{i j}\right)$. Unit prices of the individual components of the property for each transaction (adjusted for the random deviations) are expressed by Formula (10):

$$
\bar{c}_{i j}=\hat{c}_{i j} \frac{c_{T j}}{c_{T j}-\delta_{T j}}
$$

After conducting an analysis of the variance for relation (10), Formula (11) is derived for the standard deviation for adjusted unit prices of the real estate components:

$$
\sigma\left(\bar{c}_{i j}\right)=\sqrt{\left(\frac{C_{T j}}{C_{T j}-\delta_{T j}}\right)^{2} \cdot \sigma^{2}\left(\hat{c}_{i j}\right)+\left(\frac{C_{T j}}{C_{T j}-\delta_{T j}}\right)^{2} \cdot \sigma^{2}\left(\sigma_{T j}\right)}
$$

Confidence intervals for the estimated unit prices of the real estate components are defined by quantiles of the Student $t$-distribution. Adopting the confidence level $(1-\alpha)$ and number of $n$ degrees of freedom of the estimation model, it is possible determine the quantiles of Student $t$-distribution $t\left(1-\frac{\alpha}{2} ; n\right)$ based on statistical tables. 
A symmetric confidence interval for the estimated unit prices of the real estate components adopts the range according to Formula (12).

$$
\vec{c}_{i}=\hat{c}_{i} \pm t\left(1-\frac{\alpha}{2} ; n\right) \cdot \sigma\left(\hat{c}_{i}\right)
$$

If all of the properties on which the model's construction was based as well as the property being valued have identical characteristics, then the estimation of the market value of any real estate is possible by applying Formula (13):

$$
W=S_{1} \cdot \hat{c}_{1}+S_{2} \cdot \hat{c}_{2}+\ldots+S_{i} \cdot \hat{c}_{i}
$$

In this equation, the estimated unit values are used for each component of the property and surface areas corresponding to the subsequent components of the property being valued.

If the model used for valuation was constructed based on similar properties yet not identical to the property being valued, the market value determined by Formula (13) should be adjusted using Formula (14):

$$
\hat{W}=W+\Delta W
$$

Adjustment to the property value is calculated as the weighted average of the random deviations obtained in the model using Formula (15):

$$
\Delta W=\frac{\sum_{j=1}^{n} \delta_{T_{j}} p_{j}}{\sum_{j=1}^{n} p_{j}}
$$

In this case, the weights are determined by Formula (16):

$$
p_{j}=\frac{1}{0.25+\sum_{s=1}^{n}\left(a_{j s}-\bar{a}_{s}\right)^{2}}
$$

where $\bar{a}_{s}$ - value of the $s$-th attribute of the property being valued.

When assessing the inaccuracy of the property valuation, Formula (17) is used:

$$
\sigma(\hat{W})=\sqrt{\left\{S_{W}\right\} \cdot \operatorname{cov}\{\hat{c}\} \cdot\left\{S_{W}\right\}^{T}+\{P\} \cdot \operatorname{cov}\left\{\hat{\delta}_{T}\right\} \cdot\{P\}^{T}}
$$

where:

$\left\{S_{W}\right\}$ - vector of the surface areas of the valued property components,

$\{P\}$ - vector whose constituents are the weights of each property used for market analysis divided by the sum of these weights. 
The symmetrical confidence interval for the estimated market value depends on the determined by Formula (17), standard deviation $\sigma(\hat{W})$, and the quantile of the Student $t$-distribution. Adopting confidence level $(1-\alpha)$ and the number of $n$ degrees of freedom in the estimation model, it can be determined by Formula (18):

$$
\vec{W}=\hat{W} \pm t\left(1-\frac{\alpha}{2} ; n\right) \cdot \sigma(\hat{W})
$$

\section{Exemplary Valuation of Land Property Covered by Different Land-Use Zones}

In order to verify the suitability of the parametric model for the valuation of land properties covered by different land-use zones, the value of the land property located in one of Krakow's housing estates was estimated. The property being valued consisted of one cadastral plot of $3300 \mathrm{~m}^{2}$ and was located in the areas that were intended for multi-family housing $(\mathrm{WN})$, public roads $(\mathrm{KD})$, and public green spaces (ZP) in the local zoning plan.

The data necessary for the valuation of the analyzed property was acquired from the Registry of Property Prices and Values [23]. They formed the basis for the creation of a database of similar properties, which is presented in Table 1.

Table 1. Database of properties similar to the one being valued

\begin{tabular}{|c|c|c|c|c|c|c|c|c|}
\hline$\dot{z}$ & $\Xi_{\sharp}^{\Xi}$ & 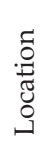 & 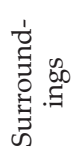 & 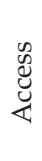 & 弚 & 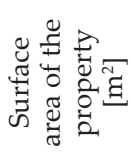 & 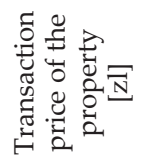 & 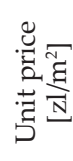 \\
\hline 1 & 0 & 1 & 2 & 1 & 0 & 3490 & 740,000 & 212 \\
\hline 2 & 2 & 2 & 2 & 2 & 1 & 4220 & $1,508,000$ & 357 \\
\hline 3 & 5 & 1 & 1 & 1 & 1 & 2690 & 880,000 & 327 \\
\hline 4 & 6 & 2 & 2 & 1 & 2 & 4840 & $1,783,000$ & 368 \\
\hline 5 & 10 & 1 & 2 & 2 & 2 & 3430 & $1,000,000$ & 292 \\
\hline 6 & 12 & 1 & 1 & 1 & 0 & 2490 & 920,000 & 369 \\
\hline 7 & 12 & 1 & 2 & 1 & 2 & 2360 & 650,000 & 275 \\
\hline 8 & 15 & 1 & 1 & 1 & 1 & 3370 & $1,050,000$ & 312 \\
\hline 9 & 17 & 1 & 1 & 1 & 1 & 2330 & 680,000 & 292 \\
\hline 10 & 18 & 1 & 2 & 2 & 1 & 3570 & $1,400,000$ & 392 \\
\hline 11 & 19 & 2 & 1 & 1 & 0 & 2850 & $1,200,000$ & 421 \\
\hline 12 & 20 & 2 & 1 & 1 & 0 & 3410 & 990,000 & 290 \\
\hline 13 & 22 & 1 & 2 & 2 & 2 & 4250 & $1,550,000$ & 365 \\
\hline 14 & 22 & 2 & 2 & 1 & 1 & 4330 & $1,300,000$ & 300 \\
\hline 15 & 24 & 1 & 2 & 2 & 1 & 4065 & $1,200,000$ & 295 \\
\hline $\mathrm{W}$ & 25 & 2 & 2 & 2 & 1 & 3300 & $?$ & $?$ \\
\hline
\end{tabular}


In order to define the influence of each attribute on the transaction prices of the properties contained in Table 1, Pearson's correlation coefficients $(r)$ between the values of these attributes and the unit transaction prices obtained for these properties were determined. The obtained values are demonstrated in Table 2.

Table 2. Correlation of unit transaction prices with attribute values

\begin{tabular}{|c|c|c|c|c|c|}
\cline { 2 - 6 } \multicolumn{1}{c|}{} & Time & Location & Surroundings & Access & Shape \\
\hline \hline$r$ & 0.12 & 0.51 & 0.43 & 0.45 & 0.32 \\
\hline$r^{2}$ & 0.01 & 0.26 & 0.18 & 0.20 & 0.10 \\
\hline
\end{tabular}

From the values contained in Table, 2 it can be concluded that time does not affect the value of real estate [12]. Therefore, there is no need to adjust the transaction prices per the valuation date. The influence of other attributes on the prices can be described as average [21].

Information from Table 1 and measurements of the surface areas performed on local land-use plans allowed us to build 15 equations that were used to determine the unit values of the properties located in the areas with the following land uses MW, KD, and ZP:

$S=\left[\begin{array}{ccc}1145 & 350 & 1690 \\ 3500 & 720 & 0 \\ 2070 & 0 & 620 \\ 4390 & 0 & 450 \\ 2300 & 150 & 980 \\ 2200 & 290 & 0 \\ 1350 & 830 & 180 \\ 2500 & 0 & 870 \\ 1400 & 690 & 240 \\ 3350 & 220 & 0 \\ 2720 & 130 & 0 \\ 2150 & 610 & 650 \\ 2780 & 0 & 470 \\ 3100 & 0 & 1230 \\ 2850 & 115 & 1100\end{array}\right]\left[\mathrm{m}^{2}\right], \quad C_{T}=\left[\begin{array}{c}740,000 \\ 1,508,000 \\ 880,000 \\ 1,783,000 \\ 1,000,00 \\ 920,000 \\ 650,000 \\ 1,050,000 \\ 680,000 \\ 1,400,000 \\ 1,200,000 \\ 990,000 \\ 1,550,000 \\ 1,300,000 \\ 1,200,000\end{array}\right][\mathrm{zl}], \quad p_{j}=\left[\begin{array}{c}0.68 \\ 0.88 \\ 2.12 \\ 0.55 \\ 0.55 \\ 0.68 \\ 0.68 \\ 2.12 \\ 2.12 \\ 1.24 \\ 0.55 \\ 0.55 \\ 0.55 \\ 1.24 \\ 1.24\end{array}\right]$

Due to the large size of matrix $\{p\}$, Formula (19) only contains the values located on the diagonal of that matrix. 
As a result of an estimation of the model parameters, the values (20) were obtained:

$$
\hat{c}=\left[\begin{array}{c}
406.17 \\
138.24 \\
43.58
\end{array}\right] \begin{array}{cc}
M W & \\
Z P &
\end{array}
$$

Based on the residual variance $\left(\sigma_{0}^{2}\right)$, whose value was $745,263,505 \mathrm{zl}^{2}\left(\hat{\sigma}_{0}=27,300 \mathrm{zl}\right)$, the covariance matrix $(\operatorname{cov}(\hat{c}))$ was calculated for the unit values of the individual property components:

$$
\operatorname{cov}(\hat{c})=\left[\begin{array}{ccc}
19.18 & -43.04 & -42.44 \\
-43.04 & 438.05 & 44.76 \\
-42.44 & 44.76 & 185.25
\end{array}\right] \quad\left[\left(\mathrm{zl} / \mathrm{m}^{2}\right)^{2}\right]
$$

The elements located on the diagonal of this matrix allow us to determine the standard deviations of the value $(\sigma(\hat{c}))$ for the respective areas:

$$
\sigma(\hat{c})=\left[\begin{array}{c}
4.38 \\
20.93 \\
13.61
\end{array}\right] \begin{array}{cc}
M W & \\
K D & {\left[\mathrm{zl} / \mathrm{m}^{2}\right]}
\end{array}
$$

Using quantile of the Student $t$-distribution for 8 degrees of freedom $(i=15$, $j=3, s=4)$ and the significance level $1-\alpha=0.95$, or $t(0.975 ; 8)=2.3060$, the symmetric confidence intervals for the estimated model values (20) equal (23).

$$
\hat{c}=\left[\begin{array}{c}
406.17 \\
138.24 \\
43.58
\end{array}\right] \pm\left[\begin{array}{c}
10.10 \\
48.26 \\
31.39
\end{array}\right] \begin{array}{cc}
M W & \\
Z P & {[\mathrm{zl} / \mathrm{m}]}
\end{array}
$$

The remaining values obtained from the estimation of the model parameters are random deviations $\left(\hat{\delta}_{T}\right)$ from the corresponding transaction prices, which are presented below along with their standard deviations $\left(\sigma\left(\hat{\delta}_{T}\right)\right)$, determined based on the covariance matrix $\left(\operatorname{cov}\left(\hat{\delta}_{T}\right)\right)$. 
Random deviations $\left(\hat{\delta}_{T}\right)$ and their standard deviations $\left(\sigma\left(\hat{\delta}_{T}\right)\right)$ equal:

$$
\hat{\delta}_{T}=\left[\begin{array}{c}
30,716 \\
-13,132 \\
12,832 \\
-19,245 \\
3349 \\
-13,665 \\
-20,736 \\
-2465 \\
5755 \\
8916 \\
77,245 \\
7731 \\
-5333 \\
-11,494 \\
-20,315
\end{array}\right][\mathrm{zl}], \quad \sigma\left(\hat{\delta}_{T}\right)=\left[\begin{array}{c}
25,939 \\
24,568 \\
17,534 \\
33,257 \\
35,556 \\
31,975 \\
29,294 \\
16,626 \\
13,584 \\
20,671 \\
35,024 \\
34,809 \\
34,371 \\
21,433 \\
22,306
\end{array}\right][\mathrm{zl}]
$$

Based on the value (24), adjusted unit values of specific areas $\left(\bar{c}_{i j}\right)$ and their standard deviations $\left(\sigma\left(\bar{c}_{i j}\right)\right)$ were determined. They are demonstrated in Table 3.

Table 3. Adjusted unit values of individual components of analyzed properties and their standard deviations

\begin{tabular}{||c|c|c|c|c|c|c||}
\hline \multirow{2}{*}{ No. } & \multicolumn{2}{|c|}{ MW } & \multicolumn{2}{c|}{ KD } & \multicolumn{2}{c||}{ ZP } \\
\cline { 2 - 7 } & $\begin{array}{c}\bar{c}_{i j} \\
{\left[\mathrm{zl} / \mathrm{m}^{2}\right]}\end{array}$ & $\begin{array}{c}\sigma\left(\bar{c}_{i j}\right) \\
{\left[\mathrm{zl} / \mathrm{m}^{2}\right]}\end{array}$ & $\begin{array}{c}\bar{c}_{i j} \\
{\left[\mathrm{zl} / \mathrm{m}^{2}\right]}\end{array}$ & $\begin{array}{c}\sigma\left(\bar{c}_{i j}\right) \\
{\left[\mathrm{zl} / \mathrm{m}^{2}\right]}\end{array}$ & $\begin{array}{c}\bar{c}_{i j} \\
{\left[\mathrm{zl} / \mathrm{m}^{2}\right]}\end{array}$ & $\begin{array}{c}\sigma\left(\bar{c}_{i j}\right) \\
{\left[\mathrm{zl} / \mathrm{m}^{2}\right]}\end{array}$ \\
\hline \hline 1 & 423.76 & 31.79 & 144.23 & 38.30 & 44.42 & 34.52 \\
\hline 2 & 402.66 & 20.30 & 137.05 & 28.70 & 42.21 & 23.99 \\
\hline 3 & 412.18 & 19.48 & 140.29 & 28.48 & 43.20 & 23.46 \\
\hline 4 & 401.83 & 25.02 & 136.77 & 32.19 & 42.12 & 28.08 \\
\hline 5 & 407.53 & 35.94 & 138.71 & 41.40 & 42.72 & 38.20 \\
\hline 6 & 400.23 & 33.13 & 136.22 & 38.79 & 41.95 & 35.48 \\
\hline 7 & 393.61 & 35.47 & 133.97 & 40.64 & 41.26 & 37.60 \\
\hline 8 & 405.22 & 16.77 & 137.92 & 26.42 & 42.47 & 21.13 \\
\hline 9 & 409.64 & 17.51 & 139.43 & 27.07 & 42.94 & 21.81 \\
\hline 10 & 408.77 & 18.13 & 139.13 & 27.44 & 42.85 & 22.29 \\
\hline 11 & 434.11 & 34.49 & 147.76 & 40.84 & 45.50 & 37.14 \\
\hline 12 & 408.12 & 35.43 & 138.91 & 40.96 & 42.78 & 37.72 \\
\hline 13 & 404.78 & 27.86 & 137.77 & 34.53 & 42.43 & 30.67 \\
\hline 14 & 402.61 & 19.13 & 137.03 & 27.89 & 42.20 & 23.00 \\
\hline 15 & 399.41 & 20.48 & 135.94 & 28.71 & 41.87 & 24.08 \\
\hline
\end{tabular}


Property value $W=1,032,062 \mathrm{zl}$ determined using the parametric model was adjusted for random deviations from the transaction prices and weights of mutual similarity between the property being valued and the analyzed properties, as presented in Formula (25):

$$
\hat{\delta}_{T}=\left[\begin{array}{c}
30,716 \\
-13,132 \\
12,832 \\
-19,245 \\
3349 \\
-13,665 \\
-20,736 \\
-2465 \\
5755 \\
8,916 \\
77,245 \\
7731 \\
-5333 \\
-11,494 \\
-20,315
\end{array}\right][\mathrm{zl}], \quad p_{j}=\left[\begin{array}{c}
0.03 \\
0.37 \\
0.04 \\
0.04 \\
0.04 \\
0.04 \\
0.07 \\
0.04 \\
0.04 \\
0.04 \\
0.07 \\
0.07
\end{array}\right]
$$

The adjustment to the previously calculated value of the property is $\Delta \mathrm{W}=-3476 \mathrm{zl}$. The ultimate market value of the property being subjected to the valuation procedure, located in different land-use zones, using the quantile of the Student $t$-distribution for 8degrees of freedom $(i=15, j=3, s=4)$ and significance level $1-\alpha=0.95$, adjusted by the determined $\Delta \mathrm{W}$ is $\vec{W}=1,028,586 \mathrm{zl} \pm 23,982 \mathrm{zl}$. The standard deviation for the adjusted value of the property being valued is $\sigma(\hat{W})=10,400 \mathrm{zl}$, which is slightly above $2 \%$ of the estimated value of the property.

\section{Verification of Significance of the Obtained Model Values}

In order to verify the significance of the estimated model parameters, the following hypotheses should be formulated:

1) the null hypothesis: the estimated parameter denoting the unit value of the relevant area is statistically insignificant, and its value (as assessed by the test) is zero, which can be written using Formula (26):

$$
H_{0}: \hat{c}_{i}=0
$$


2) the alternative hypothesis: the estimated parameter denoting the unit value of the relevant area is statistically significant, and its value (as assessed by the test) is different from zero, which can be written using Formula (27):

$$
H_{1}: \hat{c}_{i} \neq 0
$$

In order to reject the null hypothesis (or to decide that there is no basis for it), the empirical and critical values of the Student's statistics should be determined. Empirical values are calculated using Formula (28):

$$
t\left(\hat{c}_{i}\right)=\frac{\hat{c}_{i}}{\sigma\left(\hat{c}_{i}\right)}
$$

Critical values are read from the Student $t$-distribution tables for a specific significance level $\alpha$ and $(j-i-s)$ degrees of freedom.

If the empirical values are larger than the critical value, the null hypothesis is rejected in favor of the alternative hypothesis. If, however, the empirical value is less than or equal to the critical value, there are no grounds to reject the null hypothesis.

The empirical values for the individual areas)calculated for an exemplary parametric model) are equal to the following (29):

$$
\begin{gathered}
t\left(\hat{c}_{M N}\right)=\frac{406.17\left[\mathrm{zl} / \mathrm{m}^{2}\right]}{4.38\left[\mathrm{zl} / \mathrm{m}^{2}\right]}=92.73 \\
t\left(\hat{c}_{K D}\right)=\frac{138.24\left[\mathrm{zl} / \mathrm{m}^{2}\right]}{20.93\left[\mathrm{zl} / \mathrm{m}^{2}\right]}=6.60 \\
t\left(\hat{c}_{\text {ZP }}\right)=\frac{42.58\left[\mathrm{zl} / \mathrm{m}^{2}\right]}{13.61\left[\mathrm{zl} / \mathrm{m}^{2}\right]}=3.12
\end{gathered}
$$

On the other hand, the critical value for significance level $\alpha$ and 8 degrees of freedom is $=2.3060$.

Comparing the obtained results, it can be concluded that all of the unit values for the individual areas obtained using the parametric model are statistically significant with respect to the corresponding standard deviations for predetermined significance level $\alpha=0.05$.

\section{Assessing Validity of Valuation with Specifying Different Land-Use Zones}

In order to find out how specifying different land-use zones affects the estimated value of real estate, the values obtained for the property (based on which the 
parametric model was built) were compared to those values that could be determined by using the method of pairwise comparison (if all properties collected in the comparable database were used for the valuation). This comparison is valid, since all properties in the database are mainly located in multi-family residential areas, and the areas intended for public roads or public green spaces are only an addition to them.

The values for all properties collected in the comparable database and for the property being valued were determined using Formula (30):

$$
w=\hat{c}+\sum_{j=1}^{i} \Delta c_{i} \cdot\left(\bar{a}_{i}-\hat{a}_{i}\right)
$$

where:

$\hat{c}$ - average unit transaction price for all properties in the database,

$\hat{a}_{i}$ - average value of each attribute for all properties in the database,

$\bar{a}_{i}$ - value of the attribute of the property being valued,

$\Delta c_{i}$ - weighting factor calculated according to Formula (31):

$$
\Delta c_{i}=\frac{\left(c_{\max }-c_{\min }\right) \cdot k_{j}}{a_{j / \max }-a_{j / \min }}
$$

where:

$c_{\max }, c_{\min }-$ maximum and minimum unit transaction prices in the database, $a_{j / \max } a_{j / \min }-$ maximum and minimum values of each attribute in the database, $k_{j}$ - weight ratios of the individual attributes, which in the analyzed case were defined based on the squares of Pearson's correlation coefficients using Formula (32):

$$
k_{j}=\frac{r_{j}^{2}}{\sum_{j=1}^{s} r_{j}^{2}}
$$

The ultimate unit values of properties from the comparable database and the property being valued (obtained by the method of pairwise comparison and in the parametric model) are illustrated in the graph in Figure 1.

It is clearly noticeable that the values obtained in the parametric model deviate significantly from the values determined on the assumption that properties in the database were mostly intended for multi-family housing. There is no obvious dependence in this case. In exactly half of the cases, the values obtained from the parametric model exceeded the values obtained in the method of pairwise comparison. 


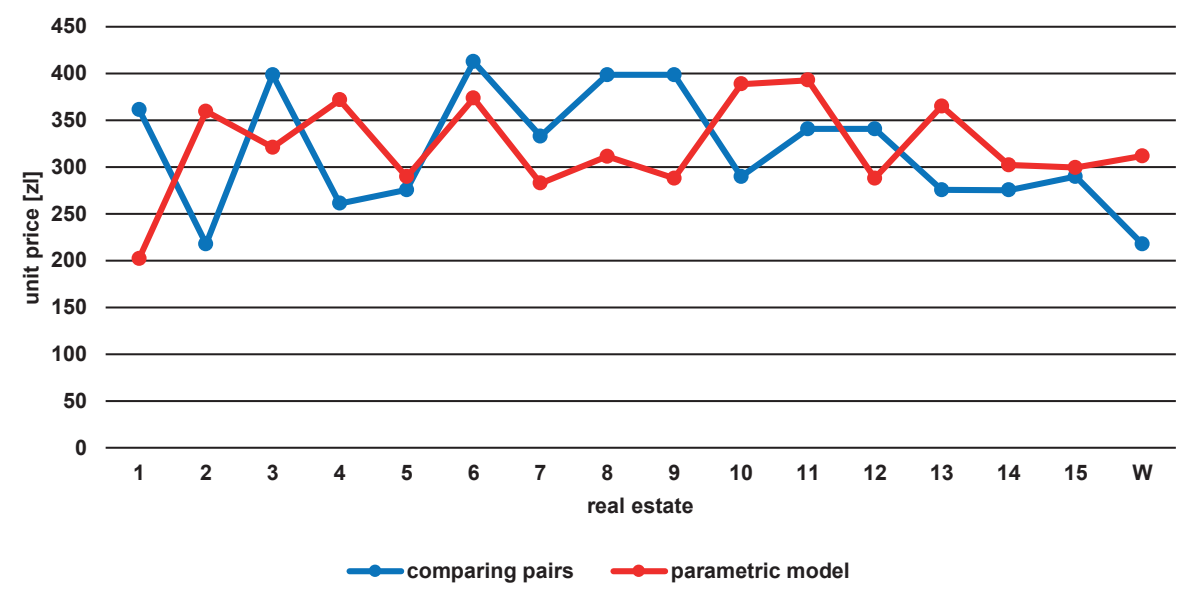

Fig. 1. Comparison of values obtained in method of pairwise comparison and in parametric model

In order to determine which values should be considered appropriate, the index of consistency between the valuation model and the comparable database was determined $(\lambda)$, expressed by Formula (33):

$$
\lambda=\frac{\sigma_{n}}{\hat{c}}
$$

where $\hat{c}$ - average unit transaction price in the database.

In order to calculate the consistency index, it is necessary to specify standard deviation $\left(\sigma_{n}\right)$ from the differences of unit transaction prices $\left(c_{i}\right)$ and estimated unit market values $\left(w_{i}\right)$ according to Formula (34):

$$
\sigma_{n}=\sqrt{\left.\frac{1}{n} \sum_{i=1}^{n} c_{i}-w_{i}\right)^{2}}
$$

For the values obtained from the parametric model, $\sigma_{n}=8.48 \mathrm{zl}$ and $\lambda=0.93$, whereas for the values determined in the method of pairwise comparison $\sigma_{n}=85.95 \mathrm{zl}$ and $\lambda=0.74$. This means that the consistency between the parametric model and the database of comparable properties is very high, while the consistency of the model used for the calculations in the method of pairwise comparison is only acceptable [21].

It is therefore reasonable in the analyzed case to take the lack of homogeneity in land-use classes into account. It can be concluded that, in the properties used for this exemplary valuation, the proportion of the areas intended for public roads and public green spaces was so large that it affected the final valuation results. 


\section{Conclusions}

The value of real estate depends largely on the possibility of its use for specific purposes (hence, on its intended land-use class in planning documents). According to all property valuation principles, each valuation procedure that involves comparing the property being valued with others should be based on properties with the same land-use class as the property being valued. Unfortunately, the lines delimiting the areas of different land-use zones often cross boundaries of cadastral parcels. As a result, the land-use class of individual properties is not always homogeneous. Individual properties may differ not only in their land-use classes but also in the proportions of different land-use zones. The presented calculations clearly indicate that it is necessary to verify whether the fact that a parcel is located in different land-use zones should be included in the property valuation procedure.

If a property being valued is located in various land-use zones, the author proposes dividing the transaction prices obtained for the whole property into individual components. For this purpose, the parametric model can be used, where the parameters are estimated using the method of least squares. Although the method of least squares is probably the most-commonly-used parameter estimation method, it should be remembered that it may not be resistant to outliers [16]. One discrepant observation is enough to completely disturb the estimation results. In the analyzed example, the use of the parametric model proved to be reasonable. However, in order to state unambiguously whether this valuation methodology should be introduced for wider use, further analyses are required to be conducted in various markets as well as for real estate with different land-use zones.

\section{References}

[1] Act of 21 August 1997 on real estate management, consolidated text of 14 December 2016. Journal of Laws of 2016, item 2147 [Obwieszczenie Marszatka Sejmu Rzeczypospolitej Polskiej z dnia 14 grudnia 2016 r. w sprawie ogłoszenia jednolitego tekstu ustawy o gospodarce nieruchomościami. Dz.U. 2016, poz. 2147].

[2] Act of 27 March 2003 on spatial planning and development, consolidated text of 11 May 2017. Journal of Laws of 2017, item 1073 [Obwieszczenie Marszałka Sejmu Rzeczypospolitej Polskiej z dnia 11 maja 2017 r. w sprawie ogłoszenia jednolitego tekstu ustawy o planowaniu $i$ zagospodarowaniu przestrzennym. Dz.U. 2017, poz. 1073].

[3] Adamczewski Z.: Elementy modelowania matematycznego w wycenie nieruchomości. Podejście porównawcze. Oficyna Wydawnicza Politechniki Warszawskiej, Warszawa 2006.

[4] Adamczewski Z., Hopfer A.: Trend udziału gruntu i budynku w wartości nieruchomości zabudowanej. Studia i Materiały Towarzystwa Naukowego Nieruchomości, t. 16, nr 3, 2008, pp. 19-32. 
[5] Adamczyk T.: Estymacja rynkowych wartości wskaźników kosztu wytworzenia i zużycia łącznego obiektów budowlanych. Geomatyka i Inżynieria: Kwartalnik Naukowy PWSZ w Jarosławiu, nr 1, 2010, pp. 29-39.

[6] Adamczyk T., Begović V., Bieda A., Bielecka E., Bugaj P., Dawidowicz A., Džunić I., Gajos M., Jankowska M., Kereković D., Krukowska K., Kryszk H., Kurowska K., Parzych P., Rahmonov O., Schrunk I., Wójciak E., Źróbek R.: Spatial Data in Wide Geospace. Nacionalna knjižnica, Zagreb 2014.

[7] Adamczyk T., Bieda A.: Intended Use of Real Estate as a Time Changeable Attribute for Determining Compensation for Nationalized and Expropriated Lands. Real Estate Management and Valuation, vol. 22, no. 4, 2014, pp. 35-50.

[8] Adamczyk T., Dąbrowski J.: Algorytm estymacji rynkowych wartości wskaźników kosztu wytworzenia i zużycia łącznego obiektów budowlanych posiadajacych różne okresy eksploatacji. Studia i Materiały Towarzystwa Naukowego Nieruchomości, t. 18, nr 1, 2010, pp. 83-93.

[9] Adamczyk T., Jasiołek J.: Podejście kosztowe w modelowaniu wartości rynkowej nieruchomości zabudowanych. Studia i Materiały Towarzystwa Naukowego Nieruchomości, t. 20, nr 2, 2012, pp. 235-246.

[10] Bieda A., Bieda A., Adamczyk T., Parzych P., 2016, The procedure for the valuation of real properties developed with passive and energy-efficient houses. [in:] SGEM 2016: $16^{\text {th }}$ international multidisciplinary scientific geoconference: informatics, geoinformatics and remote sensing: 30 June-6 July, 2016, Albena, Bulgaria: conference proceedings. Vol. 2, Geodesy and mine surveying, photogrammetry and remote sensing, STEF92 Technology Ltd., Sofia 2016, pp. 633-640.

[11] Bieda A., Hanus P., Hycner R: Geodezyjne aspekty planowania przestrzennego i wybranych opracowań projektowych. Wydawnictwo Gall, Katowice 2012.

[12] Czaja J.: Metody szacowania wartości rynkowej i katastralnej. Wydawnictwo KOMP-SYSTEM, Kraków 2001.

[13] Czaja J.: Modele statystyczne w informacji o terenie. Wydawnictwo Akademii Górniczo-Hutniczej, Kraków 1997.

[14] Czaja J., Parzych P.: Zaawansowane modele statystyczne wyceny nieruchomości zurbanizowanych. Studia i Materiały Towarzystwa Naukowego Nieruchomości, t. 16, nr 3, 2008, pp. 7-18.

[15] Kalus S., Habdas M.: Ustawa o planowaniu i zagospodarowaniu przestrzennym jako instrument kształtowania wartości rynkowej nieruchomości. Studia Iuridica Agraria, t. 10, 2012, pp. 76-91.

[16] Ligas M.: Metody statystyczne w wycenie nieruchomości. Studia i Materiały Towarzystwa Naukowego Nieruchomości, t. 18, nr 1, 2010, pp. 49-64.

[17] Parzych P.: Modele estymacji wartości rynkowej lub katastralnej nieruchomości zurbanizowanych, rolnych i leśnych. Uczelniane Wydawnictwa Naukowo-Dydaktyczne AGH, Kraków 2009.

[18] Parzych P.: Modelling of urban estates' values. Geomatics and Environmental Engineering, vol. 5, no. 4, 2011, pp. 63-72. 
[19] Parzych P.: Modelowanie wartości nieruchomości zurbanizowanych. Studia i Materiały Towarzystwa Naukowego Nieruchomości, vol. 15, no. 3-4, 2007, pp. 167-176.

[20] Parzych P., Bydłosz J.: The Algorithm of Urban Estates Valuation. [in:] FIG Hong Kong 2007: the XXX FIG general assembly and working week: 13-17 May 2007, Hong Kong: strategic integration of surveying services, 2007, pp. 1-9 [electronic document].

[21] Parzych P., Czaja J.: Szacowanie rynkowej wartości nieruchomości. Wydawnictwa AGH, Kraków 2015.

[22] Preweda E.: Rachunek wyrównawczy $\Rightarrow$ modele statystyczne. Progres Wydawnictwo Druk Reklama, Kraków 2013.

[23] Rejestr cen i wartości nieruchomości prowadzony przez Urząd Miasta w Krakowie [Register of Real Estate Prices and Values kept by the Kraków City Office] [updated: 15.06.2016].

[24] Wiśniewski Z.: Rachunek wyrównawczy w geodezji (z przykładami). Wydawnictwo Uniwersytetu Warmińsko-Mazurskiego, Olsztyn 2005.

[25] Zyga J.: Istota podobieństwa w procedurach wyceny nieruchomości. Rzeczoznawca Majątkowy, t. 75, nr 3, 2012, pp. 22-26.

\section{Model parametryczny wyceny nieruchomości gruntowych położonych w obszarach o różnym przeznaczeniu}

Streszczenie: W efekcie różnorodnych uwarunkowań planowania przestrzennego powstają linie rozgraniczające tereny o różnym przeznaczeniu, które bardzo często przecinają granice katastralne. W ten sposób pojedyncze nieruchomości gruntowe mogą znaleźć się w obszarach o różnym przeznaczeniu.

Ponieważ przeznaczenie jest jedną z tych cech, która ma znaczny wpływ na wartość rynkową nieruchomości, zasadne wydaje się sprawdzenie, czy niejednorodne przeznaczanie nieruchomości powinno być uwzględniane w wycenie nieruchomości w sposób szczególny.

Jedną z możliwości specjalnego postępowania w takim przypadku jest rozdzielenie cen transakcyjnych otrzymywanych za nieruchomości podobne do nieruchomości wycenianej, która jest położona w obszarach o różnym przeznaczeniu, na składowe cen odpowiadające fragmentom nieruchomości o konkretnym przeznaczeniu. Postępowanie takie umożliwia część modeli statystycznych, które mogą być wykorzystywane w podejściu porównawczym.

Celem artykułu jest zaprezentowanie możliwości zastosowania modelu parametrycznego do wyceny nieruchomości gruntowych objętych obszarami o różnym przeznaczaniu oraz sprawdzenie, czy zasadne jest uwzględnianie niejednorodności w przeznaczeniu nieruchomości gruntowych podczas określania ich wartości.

Słowa

kluczowe: model parametryczny, obszary o różnym przeznaczaniu, przeznaczenie nieruchomości, wycena nieruchomości 